\title{
PEMBELAJARAN IPA TERPADU MELALUI PROJECT BASED LEARNING DALAM MELATIHKAN ACADEMIC DAN SOCIAL SKILL SISWA SMP
}

\author{
Anis Shofatun'), Muslimin Ibrahim²), Wasis ${ }^{3)}$ \\ ${ }^{1)}$ Mahasiswa Program Studi Pendidikan Sains, Program Pascasarjana Universitas Negeri Surabaya \\ ${ }^{2), 3)}$ Dosen Pascasarjana Prodi Pendidikan Sains Universitas Negeri Surabaya \\ E-mail: -
}

\begin{abstract}
Abstrak: Penelitian ini bertujuan mendeskripsikan kepraktisan dan keefektifan pembelajaran IPA terpadu melalui pembelajaran berbasis proyek dalam melatihkan keterampilan akademik dan sosial siswa kelas VIIF SMP Muhammadiyah 12 GKB Gresik. Penelitian ini menggunakan one group pretest -posttest design yang di dahului dengan tahap persiapan yang bertujuan mengembangkan perangkat mengikuti rancangan 4-D model dari Thiagarajan dan dilanjutkan dengan tahap uji coba di kelas. Hasil penelitian ini menunjukkan: 1) perangkat pembelajaran berkategori praktis ditinjau dari keterlaksanaan rencana pembelajaran dan respon positif siswa terhadap pembelajaran berbasis proyek; 2) Pembelajaran menggunakan perangkat yang dikembangkan berkategori efektif, hal ini didasarkan pada: (a) penilaian keterampilan akademik siswa dalam mengorganisir materi, keterampilan merencanakan, melaksanakan dan melaporkan penugasan proyek, keterampilan unjuk kerja laboratorium menunjukkan sangat baik (b) penilaian keterampilan sosial siswa dalam bekerjasama dan berkomunikasi menunjukkan sangat baik (c) peningkatan hasil belajar pengetahuan siswa dengan rata-rata $\mathrm{N}$-gain sebesar 0,8 (gain tinggi). Berdasarkan hasil penelitian di atas dapat disimpulkan bahwa pembelajaran berbasis proyek praktis dan efektif dalam melatihkan keterampilan akademik dan sosial siswa SMP serta meningkatkan hasil belajar pengetahuan pada mata pelajaran IPA Terpadu.
\end{abstract}

Kata kunci: IPA Terpadu, Project Based Learning, Academic Skill, Social Skill

\begin{abstract}
This research aims to describe practicality and effectiveness of the integrated science learning through project-based learning in fasilitate academic and social Skill of class VIIF SMP Muhammadiyah 12 GKB Gresik. This research uses one group prettest-posttest design proceded by preparatory phase which aims to develop the material planning of the 4-D models of Thiagarajan and followed by implementation phase in the classroom. The results showed:1) the practicality of teaching material categorized in feasibility of lesson plan and students give positive responses toward teaching materials and implementation of project based learning, 2) the teaching and learning use the teaching material development categorized effectively in terms of : (a) an assessment of the student's academic skills in organizing materials, skills to plan, implement and report on project task and psychomotor student in the laboratory showed very good (b) assessment of social skills of students in collaboration and communication showed very good and (c) increased knowledge learning outcomes of students with an average of $0.8 \mathrm{~N}$-gain (high gain). Based on the result, it can be concluded that project based learning in teaching integrated natural science for Junior High Students is practicable and effectively to fasilitate student's academic and social skill and gaining their knowledge.
\end{abstract}

Keywords: Integrated Natural Science Learning, Project Based Learning, Academic Skill, Social Skill

\section{PENDAHULUAN}

Penyediaan Sumber Daya Manusia (SDM) yang siap terhadap tantangan, persaingan dan permasalahan yang kompleks menjadi salah satu tugas pendidikan di Indonesia. Pendidikan dengan upaya untuk mempersiapkan SDM yang handal dan kompeten agar mampu bersaing di pasar global nantinya. Pengembangan pembelajaran diharapkan dapat mentransformasi sumber daya manusia yang memiliki kompetensi dan keterampilan hidup sehingga menjadi sumber daya manusia yang mandiri dalam menciptakan lapangan pekerjaan, tidak bergantung pada orang lain dan negara serta mampu bersaing secara positif di pasar global (Depdikbud, 2013)

Pembelajaran IPA Terpadu Melalui Project Based Learning dalam...
Fakta dilapangan menunjukkan kondisi prestasi generasi muda saat ini cukup mengkhawatirkan. Hasil Trends in International Mathematics and Science Study (TIMSS) tahun 2011 menempatkan Indonesia pada posisi rendah pada survei tersebut yaitu 54\% mencapai tingkat rendah dan hasil PISA (Programme for International Student Assessment) tahun 2009, menunjukkan sekitar $65 \%$ peserta Indonesia tidak mencapai tingkat 2 dalam sains (Mukhlish, 2013). Hal ini mengindikasikan bahwa penguasaan dasar-dasar sains dan matematika siswa di Indonesia sangat rendah sehingga dikhawatirkan akan mengalami kesulitan termasuk perolehan pekerjaan disaat hidup di abad 21 . Sementara dalam pembelajaran sains, guru banyak 
fokus pada aspek kognisi dengan siswa menghafal konsep, teori dan puas dengan prestasi nilai akhir yang tinggi melalui metode ceramah, diskusi dan latihan soal yang bervariasi dengan mengesampingkan keterampilan proses sains dan keterampilan sosial siswa. Harapan besarnya pendidikan di Indonesia diarahkan pada pembelajaran yang mengedepankan penalaran dan sikap kritis dalam menanggapi persoalan yang terjadi di lingkungan dan masyarakat sehingga siswa memiliki keterampilan dan mampu memberikan solusi secara cerdas dan bersikap secara bijak dalam menanggapi isu-isu pribadi, masyarakat dan lingkungan.

Permasalahan utama yang dihadapi dalam pembelajaran saat ini adalah masih rendahnya daya serap siswa terhadap materi dan kondisi pembelajaran yang masih bersifat konvensional dan kurang menyentuh ranah dimensi siswa itu sendiri, yaitu bagaimana belajar dan dari belajar dapat memotivasi diri atau dengan kata lain proses pembelajaran masih terlihat dominansi dari guru dan belum memberikan akses bagi siswa untuk berkembang secara mandiri melalui penemuan ilmiah serta kurang memberikan pengalaman kepada siswa untuk dapat menyelesaikan permasalahan yang tidak sebatas teoritis saja namun juga permasalahan nyata dan menantang yang terjadi dalam kehidupan sehari-hari.

Berbekal pengetahuan teoritis yang telah dikuasainya, siswa dapat diharapkan mampu memiliki kemampuan dalam menyelesaikan masalah secara tepat dan dengan kerja intelektualnya mampu memberikan solusi pemecahan masalah secara kreatif, inovatif dan komprehensif. Namun, dengan memiliki kecakapan bidang akademik saja tidaklah cukup untuk menghadapi permasalahan yang kompleks yang sering dihadapi dalam kehidupan sehari-hari, perlu ada sinergi dengan lingkungan termasuk dengan melakukan interaksi dengan sesama sehingga pemecahan masalah tersebut akan lebih mudah diselesaikan. Karena dengan berkolaboratif siswa dapat saling memberikan motivasi dan memperkuat ide gagasan, sehingga guru selaku fasilitator dituntut pula untuk melatihkan keterampilan sosial siswa selama mengajarkan pembelajaran dikelas. Pengintegrasian kedua keterampilan tersebut mengharuskan setiap tindakan belajar dari siswa melibatkan aspek fisik, mental, emosional dan intelektualnya.

Topik materi sains tentang energi dalam sistem kehidupan erat kaitannya dengan aplikasi kehidupan sehari-hari. Bahkan persoalan kontekstual berkenaan dengan energi banyak membuat resah masyarakat. Topik materi ini akan lebih komprehensif melatihkan keterampilan siswa dengan memadukan beberap subsub materi terkait seperti konsep energi kehidupan, berbagai bentuk energi, termodinamika, transformasi energi, dan proses metabolism tubuh. Pembelajaran IPA secara terpadu, akan menunjukkan keterkaitan unsurunsur konseptual yang berpengaruh terhadap kebermaknaan pengalaman belajar (Forgaty, 1991). Diharapkan dengan keterkaitan konseptual yang dipelajari dari unsur-unsur dalam bidang studi IPA yang relevan akan membuat skema kognitif, sehingga siswa akan memperoleh keutuhan dan kebulatan pengetahuan, serta kebulatan pandangan tentang kehidupan, dunia nyata dan fenomena alam. Selain itu, kecakapan berpikir dan kecakapan bertindak dalam berinteraksi dengan teman dan lingkungannya menjadi kunci kesuksesan penyelesaian masalah. Salah satu cara untuk mengemas pembelajaran bermakna berbasis masalah kontekstual adalah melalui penugasan proyek. Metode ini cukup menantang dan dianggap sebagai alat yang efektif untuk pembelajaran siswa karena mereka didorong untuk tidak bergantung sepenuhnya pada guru, tapi diarahkan untuk dapat mengorganisir materi dan diri secara mandiri.

Pembelajaran berbasis proyek (Project Based Learning) merupakan metode pembelajaran yang mengacu pada filosofi konstruktivisme yaitu pengetahuan merupakan hasil konstruksi kognitif melalui aktivitas siswa yang meliputi keterampilan ataupun sikap ilmiah sehingga siswa dapat mengonstruksi pengetahuannya sendiri dan bermakna melalui pengalaman nyata. Kerja proyek yang memuat tugas-tugas yang kompleks berdasarkan pertanyaan dan permasalahan (problem) yang sangat menantang dan menuntut siswa untuk merancang, memecahkan masalah, membuat keputusan, melakukan kegiatan investigasi serta memberikan kesepatan kepada siswa untuk bekerja secara mandiri (Okudan, 2004).

Menurut Rais (2010) Pembelajaran berbasis proyek dapat dipandang sebagai salah satu pendekatan penciptaan lingkungan belajar yang dapat mendorong siswa mengkonstruk pengetahuan dan keterampilan secara personal. Pembelajaran berbasis proyek akan memberikan kesempatan kepada siswa belajar secara mandiri sehingga mampu mengkonstruksi pengetahuan sendiri dan selanjutnya mampu menerapkan dalam penyelesain proyek dan mengaplikasikan dalam kehidupan sehari-hari.

Menurut Nurhadi dan Senduk (2004) pembelajaran berbasis proyek memiliki 4 ciri sebagai berikut : 1) adanya pengajuan masalah atau pertanyaan yang berorientasi pada situasi kehidupan nyata yang autentik dan memungkinkan adanya berbagai macam solusi, 2) berfokus pada keterkaitan antar disiplin ilmu 3) Penyelidikan autentik, mengharuskan siswa melakukan penyelidikan autentik untuk mencari penyelesaian nyata terhadap masalah nyata. 4) menghasilkan produk/karya nyata atau artefak, laporan, model dan peragaan yang menjelaskan atau mewakili bentuk masalah yang 
mereka temukan. Project-based learning (Pembelajaran Berbasis Proyek) sebagai model pembelajaran yang kooperatif dan akomodatif terhadap kemampuan siswa menuju proses berpikir yang bebas dan kreatif. Implementasi Pembelajaran Berbasis Proyek ialah pada keikutsertaan siswa dalam memahami realitas kehidupan dari yang konkret sampai yang abstrak. Realitas kehidupan ini akan menjadi sumber inspirasi dan kreativitas dalam melakukan analisis dan membangun visi kehidupan. Menurut Kemendikbud (2013) Pembelajaran berbasis proyek memiliki 6 langkah yaitu : (1) penentuan pertanyaan mendasar (Start With the Essential Question), (2) mendesain perencanaan proyek (Design a Plan for the Project), (3) menyusun jadwal (Create a Schedule), (4) memonitor siswa dan kemajuan proyek (Monitor the Students and the Progress of the Project), (5) menguji hasil (Assess the Outcome) dan (6) mengevaluasi pengalaman (Evaluate the Experience)

Pembelajaran proyek memuat tugas-tugas yang kompeks berdasarkan pada pertanyaan dan permasalahan (problem) yang sangat menantang dan menuntut siswa untuk merancang, memecahkan masalah, membuat keputusan, melakukan kegiatan invetsigasi, serta memebrikan kesempatan kepada siswa untuk bekerja secara mandiri. Untuk itu perlu melakukan penelitian tentang pengaruh pembelajaran berbasis proyek dalam pembelajaran kimia terhadap keterampilan proses sains ditinjau dari gaya kognitif siswa.

Tujuan dari penelitian ini adalah untuk mendeskripsikan kepraktisan dan keefektifan pembelajaran berbasis proyek dalam melatihkan keterampilan akademik dan keterampilan sosial siswa SMP. Adapun tujuan dari penelitian ini adalah sebagai berikut : (1) mendeskripsikan kepraktisan pembelajaran berbasis proyek dalam melatihkan keterampilan akademik dan keterampilan sosial, (2) mendeksripsikan keterampilan akademik siswa SMP melalui pembelajaran berbasis proyek, (3) mendeksripsikan keterampilan sosial siswa SMP melalui pembelajaran berbasis proyek dan (4) Mendeskripsikan hasil belajar pengetahuan siswa pada pembelajaran IPA Terpadu melalui pembelajaran berbasis proyek.

\section{METODE PENELITIAN}

Penelitian ini dilaksanakan dalam dua tahap yaitu tahap pengembangan perangkat pembelajaran dengan model 4-D dari Thiagarajan dkk (1991). Pengembangan perangkat pembelajaran ini terdiri atas empat langkah yaitu Define, Design, Develop dan Disseminate. Tahap kedua yaitu implementasi pembelajaran IPA Terpadu di kelas dengan 8 kali pertemuan pada materi pokok energi dalam sistem kehidupan. Rancangan penelitian menggunakan One Group Pretest and Postest Design dengan tujuan mengetahui efektifitas perlakukan sebelum dan sesudah pembelajaran berbasis proyek diberikan kepada siswa. Sampel dalam penelitian ini adalah siswa kelas VIIF SMP Muhamadiyah 12 GKB Gresik sejumlah 31 orang. Penelitian ini dilaksanakan pada bulan januari-februari 2015.

Variabel penelitian yang digunakan meliputi dua hal yaitu (1) variabel yang terkait dengan kepraktisan pembelajaran berbasis proyek yang meliputi keterlaksanaan rencana pembelajaran dan kendalakendala yang muncul selama pembelajaran berangsung dan, (2) variabel yang terkait dengan keefektifan pembelajaran berbasis proyek yang meliputi keterampilan akademik, keterampilan sosial, hasil belajar pengetahuan, dan respon siswa terhadap penerapan pembelajaran berbasis proyek.

Beberapa istilah dalam penelitian ini dijelaskan agar tidak menimbulkan penafsiran lain, bagai berikut.

1. Pembelajaran IPA Terpadu adalah pembelajaran yang dilakukan dengan menggunakan pendekatan integratif semua bidang kajian untuk memecahkan permasalahan, sehingga siswa memiliki pengetahuan IPA secara utuh untuk dapat memecahkan permasalahan hidup secara kontekstual. (Puskur, 2007)

2. Pembelajaran berbasis proyek (PjBL) merupakan suatu model pembelajaran yang mengkondisikan dan memaksa siswa mencari solusi pemecahan masalah dalam menyelesaikan proyeknya (Cheong \& Christine, 2002).

3. Keterampilan akademik (Academic skill) merupakan kecakapan yang terkait dengan bidang pekerjaan yang lebih memerlukan pemikiran atau kerja intelektual (Depdiknas, 2009).

4. Keterampilan sosial (Social skill) atau merupakan perilaku-perilaku yang mendukung kesuksesan hubungan sosial dan memungkinkan individu untuk bekerjasama dengan orang lain secara efektif (Arends, 2008).

Instrumen penelitian yang digunakan meliputi : lembar observasi, lembar tes, lembar penilaian kinerja dan lembar penilaian kreativitas produk serta lembar respon siswa terhadap implementasi PjBL. Lembar observasi digunakan untuk mengetahui tingkat efektivitas pembelajaran yang diperoleh dari pengamatan keteraksanaan rencana pembelajaran dan pengamatan terhadap perkembangan keterampilan sosial siswa yang meliputi keterampian berkomunikasi dan keterampilan bekerjasama. Keterampilan bekerjasama siswa terdiri atas 6 indikator yaitu mengerjakan tugas sebagaimana yang telah diberikan dan disepakati dalam kelompok, bersama kelompok melakukan perbaikan bila ternyata terjadi kekeliruan, melaporkan hasil kerja yang telah diberikan oleh 
kelompok, memberikan kontribusi dalam penyelesaian tugas kelompok, selalu berada dalam kelompoknya dan memiliki pembagian kerja dalam penyelesaian tugas kelompok. Keenam indikator tersebut diamati oleh 2 orang pengamat selama 8 kali pembelajaran. Sedangkan keterampian berkomunikasi siswa memiliki 3 indikator yaitu menghargai pendapat orang lain, menjadi Pendengar yang baik, mengkomunikasikan materi dengan runtut dan penuh percaya diri. Lembar penilaian kinerja digunakan untuk mengukur keterampilan akademik siswa yang meliputi keterampilan dalam mengorganisir materi, merencanakan dan menghasilkan kreativitas produk sains, serta keterampilan psikomotorik (unjuk kerja) di laboratorium. Lembar tes digunakan untuk mengukur penguasaan konsep siswa sebelum dan sesudah mengikuti pebelajaran berbasis proyek. Semua data yang diperoleh kemudian dianalisis secara deskripsi kuantitatif.

\section{HASIL PENELITIAN DAN DISKUSI}

Hasil penelitian ini menunjukkan bahwa $84,21 \%$ pembelajaran yang dirancang dengan menggunakan sintaks pembelajaran berbasis proyek berorientasi masalah terlaksana dengan baik dan memiliki reliabilitas sebesar $96,38 \%$ selama 8 kali pertemuan. Hal ini menunjukkan kegiatan pembelajaran yang di awali dengan pengajuan pertanyaan atau masalah autentik terkait energi dalam sistem kehidupan yang disajikan dari sumber terkini dengan menstimulasi siswa untuk menemukan berbagai macam solusi sesuai kreativitasnya. Pembelajaran yang berfokus pada keterkaitan antar disiplin ilmu, penyelidikan yang autentik untuk mencari penyelesaian nyata terhadap permasalahan nyata dan menghasilkan produk dapat memberikan pengalaman belajar yang lebih berarti bagi siswa. Pembelajaran ini sesuai dengan pandangan Dewey yang menyatakan bahwa kelas seharusnya menjadi laboratorium untuk penyelidikan kehidupan nyata dan pemecahan masalah (Nur, 2011). Pembelajaran dengan mengelola siswa berada dalam kelompok-kelompok kecil untuk mengerjakan proyekproyek pilihan sesuai dengan minat mereka sendiri sehingga pembelajaran menjadi lebih bermakna.

Keterampilan akademik yang dilatihkan melalui PjBl dalam penelitian ini adalah keterampilan dalam mengorganisir materi, keterampilan merencanakan, melaksanakan dan melaporkan kegiatan proyek dan keterampilan unjuk kerja di laboratorium. Keterampilan dalam mengorganisir materi menunjukkan sebanyak $77 \%$ siswa memiliki keterampilan sangat baik dalam mengorganisir materi energi dalam kehidupan dan $20 \%$ siswa memiliki keterampilan dengan kategori baik dan hanya 3\% dengan ketegori cukup baik. Hal ini menunjukkan bahwa aktivitas belajar kolaboratif siswa melalui pembelajaran berbasis proyek dapat melatihkan keterampilan mengorganisir materi pembelajaran sehingga siswa dapat memahami konsep secara keseluruhan dengan menghubungkan antar subkonsep yang ada sebagai bekal pengetahuan dalam melaksanakan dan menyelesaikan tugas proyek. Dalam penyelesaian proyek, siswa melakukan diskusi secara kolaboratif dan disaat kelompok menyusun laporan, setiap anggota kelompok ikut berkontribusi mengambil bagian pada konten yang akan di bahas. Kondisi seperti ini penting untuk memilih leader (pemimpin) yang memiliki keterampilan dalam mengorginisr anggota, waktu dan tugas. Proses penyelesaian tugas secara kolaboratif, akan bisa berjalan dengan optimal bila setiap siswa saling menyubangkan ide, gagasan dan kreativitas sebelum di bawa di forum kelompok. Selain itu dengan berkolaboratif ide kreativitas akan muncul jauh lebih baik daripada hanya di pikirkan oleh seorang anggota kelompok saja. (Slavin, 1995)

Siswa distimulasi dengan permasalahan nyata yang dapat menumbuhkan rasa keingintahuan dalam memahami kondisi kehidupan disekitarnya sehingga belajar secara kolaboratif bersama temannya akan memicu pikirannya untuk mengonstruksi pengetahuan mereka sendiri. Kondisi seperti ini sesuai dengan prespektif kognitif konstruktivis Piaget yang menyatakan bahwa siswa dengan terlibat secara aktif dalam proses mendapatkan informasi dan mengonstruksikan pengetahuannya sendiri. Pengetahuan tersebut tidak statis, tetapi berevolusi dan berubah secara konstan selama siswa mengkonstruksikan pengalaman- pengalaman baru yang memaksa mereka untuk mendasarkan diri pada dan memodifikasi pengetahuan sebelumnya (Arends,2008).

Perencanaan kegiatan belajar mengajar disusun berdasarkan teori konstruktivisme. Pada pembelajaran berbasis proyek, siswa distimulasi dengan permasalahan dan aktivitas yang manantang. Selanjutnya, siswa dalam kelompok dituntut secara mandiri untuk bisa berkolaborasi dalam menyumbangkan ide, menyelesaikan permasalahan dan mengorganisasi aktivitas belajarnya. Kondisi ini mendorong siswa untuk berpikir lebih jauh dalam memperoleh pengetahuan dan pengalaman belajarnya. Sedangkan pembelajaran berbasis proyek berfokus pada kreatifitas berpikir, pemecahan masalah dan interaksi antara siswa dengan teman sebaya untuk menciptakan dan menggunakan pengetahuan baru sehingga dapat menciptakan lingkungan belajar yang dapat mendorong siswa mengonstruksi pengetahuan mereka sendiri dan keterampilan personal melalui pengalaman yang nyata. Selanjutnya, siswa dengan melakukan eksperimen dapat mengorganisir kembali pengetahuan yang diperolehnya dan dapat mengasimiasi informasi baru dan kemudian 
dikonstruksikan melalui pikirannya mereka sendiri (Bass dkk, 2005)

Pengamatan terhadap keterampilan akademik melalui pembelajaran berbasis proyek juga terlihat pada keterampilan siswa dalam melakukan serangkaian proses penugasan proyek yang terdiri atas 3 tahap yaitu (1) tahap persiapan, yang meliputi merencanakan dan mendesain produk energi biomassa serta mempersiapkan alat dan bahan yang dibutuhkan; (2) tahap pelaksanaan, yang meliputi keterampilan merangkai alat, melakukan pengamatan, menganalisa data dan membuat kesimpulan dan (3) tahap pelaporan, yang meliputi performance presentasi dan penguasaan materi.

Tingkat keterampilan siswa dalam melaksanakan penugasan proyek dapat dilihat pada gambar 1 berikut ini :

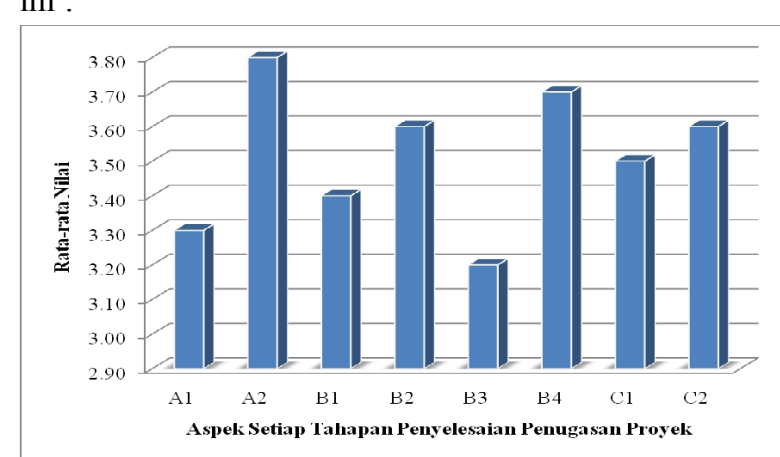

Gambar 1. Tingkat aspek keterampilan penyelesaian penugasaan proyek siswa

Keterangan :

A1: Merencanakan dan mendesain produk

A2: Mempersiapkan alat dan bahan

B1: Merangkai alat

B2: Melakukan pengamatan,

B3: Menganalisa data hasil pengamatan

B4: Membuat pelaporan

$\mathrm{C} 1$ : Penampilan (Performance) produk dan

$\mathrm{C} 2$ : Penguasaan materi

Berdasarkan gambar 1 terlihat perolehan skor siswa pada tahap awal (persiapan proyek) mencapai 106,50 dari skor total 120 atau mencapai $84,07 \%$ dari jumlah siswa, kemudian pada tahap pelaksanaan proyek meningkat menjadi 104,25 atau mencapai $84,48 \%$ dari jumlah siswa hingga pada tahap pelaporan, perolehan skor keterampilan proyek siswa mencapai 106,50 atau $84,07 \%$ dari jumlah siswa. Hal ini menunjukkan bahwa keterampilan siswa dalam melakukan serangkaian tahapan kegiatan penugasan proyek terus mengalami peningkatan sehingga pembelajaran berbasis proyek dapat melatihkan sejumlah keterampilan akademik siswa.

Selama penyelesaian penugasan proyek yang berlangsung dalam jangka waktu yang relatif lama dan kompleks, siswa banyak melakukan kerja secara otonom baik dalam menentukan ide kreativitas, mengorganisir waktu dan memanagemen tugas anggota kelompok, keaktifan melakukan bimbingan serta pencapaian target penyelesaian proyek. Selain itu, siswa memiliki kesempatan untuk bersaing dengan kelompok lain untuk penyesaian tugas proyek sehingga sebagaian besar siswa menjadi lebih antusias dan aktif. Hal ini juga terlihat dari hasil respondensi yang menunjukkan bahwa $60 \%$ menyatakan menjadi lebih aktif dan $30 \%$ siswa menyatakan lebih bebas mengemukan pendapat dan $60 \%$ menjadikan siswa yang semua pasif dalam berinteraksi dan berkomunikasi menjadi mulai merasa mendapatkan peluang untuk bebas bertindak dan berpendapat selama proses pembelajaran. Pembelajaran berbasis proyek,guru banyak berperan sebagai fasilitator dalam menstimulasi ide dan kreatifitas serta memotivasi siswa untuk terus berusaha fokus pada tujuan yang ingin dicapai. Bahkan dalam pembelajaran berbasis proyek, siswa dan guru menambah aktivitas belajar di luar jam belajar efektif berdasarkan kebutuhan dan kemauan (motivasi) siswa itu sendiri.

Kelemahan siswa dalam menganalisa hasil pengamatan terlihat pada kurang cermat dan telitinya siswa dalam melakukan pengamatan. Kondisi seperti ini terlihat LK 04 pada point 3 dan 4, terdapat $30 \%$ siswa saja yang dapat mengidentifikasi dengan benar dan mandiri bentuk energi yang terdapat pada bahan dasar yang kemudian mengalami perubahan bentuk energi lain sepanjang proses pembuatan kreativitas produk energi biomassa. Sedangkan selebihnya yaitu $56,67 \%$ siswa memerlukan bimbingan dalam menentukan proses transformasi energi dan 1,33\% lainnya belum bisa mengidentifikasi bentuk energi yang terlibat selama proses pembuatan energi biomassa. Sehingga penguatan konsep terkait energi terus ditingkatkan melalui diskusi dan latihan soal. Namun, melalui pengamatan secara langsung produk yang ada, siswa memperoleh gambaran secara konkret bagaimana konsep transformasi energi berlangsung dalam rangkaian alat ataupun proses metabolism baik dalam tubuh makhluk hidup yang mutiseluler dan uniseluler misalnya pada pembuatan biogas dari tanaman Enceng Gondok (Eichernia crassipes).

Keterampilan unjuk kerja siswa dalam setiap aspek pembelajaran di laboratorium dapat berikut ini:

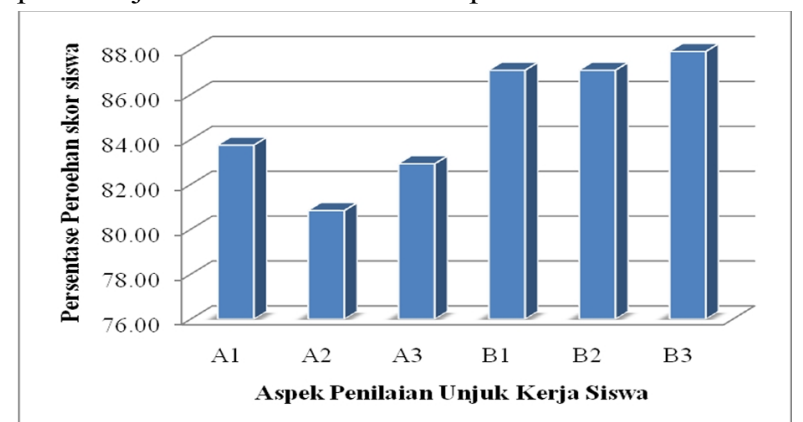

Gambar 2. Persentase nilai rata-rata aspek keterampilan unjuk kerja siswa 


\section{Keterangan :}

A1 $=$ Merangkai alat dalam percobaan respirasi

A2 $=$ Memasukkan larutan eosin ke tabung respirometer

A3 = Melakukan pengukuran pergerakan larutan eosin

B1 = Mempersiapkan dan merangkai alat dalam percobaan Sach

B2 $=$ Melarutkan klorofil

B3 = Menguji keberaan amilum dengan larutan lugol

Gambar 2 menunjukkan stimulasi siswa melalui penugasan proyek melatihkan keterampilan unjuk kerja laboratorium siswa sebesar $84,38 \%$. Pembelajaran berbasis proyek juga menjadikan siswa aktif untuk melakukan observasi dan penelitian termasuk eksperimental laboratorium. Hal ini sesuai dengan pedagogi Dewey yang mendorong guru untuk melibatkan siswa diberbagai proyek berorientasi masalah dan membantu mereka menyelidiki berbagai masalah sosial dan intelektual lainnya. Hal ini telah dibuktikan oleh hasil penelitian Muderawan dkk (2013) yang menyebutkan bahwa pembelajaran berbasis proyek memberikan pengaruh cukup signifikasn terhadap keterampilan proses sains siswa. Pada gaya kognitif yang sama yaitu Field Independent (FI) terlihat bahwa siswa dengan pembelajaran berbsis proyek menunjukkan memiliki keterampilan proses sains yang lebih baik dari pada kelas konvensional dengan nilai rata-rata 86,82 kelas $\mathrm{PjBl}$ dan 70,29 kelas konvensional

Pada penelitian ini, terdapat dua jenis keterampilan sosial yang menjadi variabel penelitian yaitu keterampilan bekerjasama dan keterampilan berkomunikasi. Hasil pengamatan terhadap keterampilan bekerjasama siswa dalam penyelesaian tugas kelompok yang dilaksanakan selama proses pembelajaran proyek yang berlangsung selama 8 kali pertemuan menunjukkan rata-rata sebesar $97.50 \%$. Data hasil penelitian terkait aspek keterampilan bekerjasama selama implementasi pembelajaran berbasis proyek dapat di lihat pada gambar 3 berikut ini :

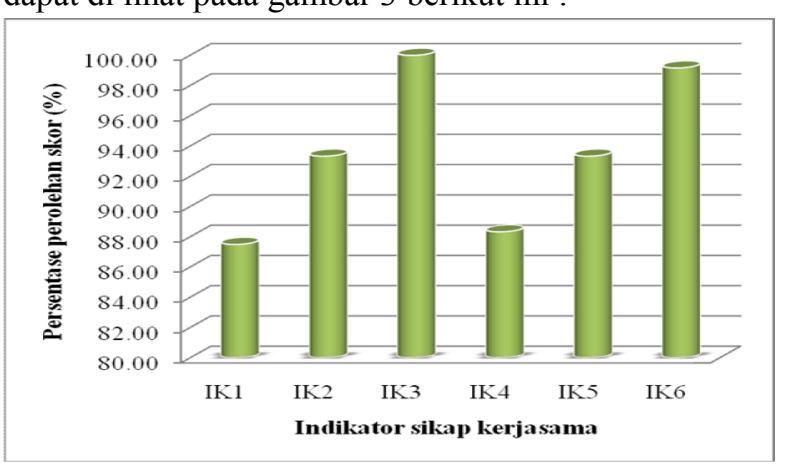

Gambar 3. Persentase perolehan modus nilai indikator keterampilan bekerjasama

Gambar 3 di atas menunjukkan bahwa pemberian pengalaman belajar siswa melalui pembelajaran berbasis proyek dengan melibatkan siswa secara aktif dan bebas berinteraksi dengan lingkungan dapat melatihkan sejumlah keterampilan sosial terutama keterampilan bekerjasama. Aktivitas kerjasama siswa terlihat selama proses pembelajaran berlangsung seperti berusaha untuk membantu penyelesaian proyek sesuai dengan tanggungjawab yang telah diberikan kepadanya, saling memberikan bantuan dan masukan dalam menghasilkan kreatifitas produk terbaik dan memberikan dukungan moral kelompok dengan tetap berada dalam kelompoknya selama penyelesaian penugasan proyek dan lain sebagainya. Pada IK3 terkait berkontribusi dalam melaporkan hasil kerja sebagaimana yang telah diberikan oleh kelompok mencapai $98 \%$ dan IK6 terkait memiliki pembagian kerja dalam penyelesaian tugas kelompok mencapai 99\%. Kondisi ini menunjukkan bahwa mengembangkan suasana belajar dengan menciptakan hubungan belajar secara berkelompok dan multi arah antara siswa dengan berbagai sumber belajar dapat mewujudkan kreativitas secara optimal, terarah dan terbimbing. Hal ini sejalan dengan pandangan temuan DeVries dan Zan (1994) yang antara lain menyatakan bahwa aktivitas belajar yang mengintegrasikan aktivitas- aktivitas sosial, akademis, dan aktivitas moral dapat mengembangkan kemampuan berpikir konseptual dan akademis, berpikir kritis, mengembangkan keterampilan-keterampilan sosial, serta membantu meningkatkan penalaran nilai dan moral siswa secara mantap, mandiri, dan bermakna (Joyce \& Weil, 2009).

Kegiatan diskusi kelompok yang dilakukan oleh siswa memberikan manfaat sosial dan motivasional bagi siswa serta membantu siswa dalam menarik kesimpulan dan mengembangkan solusi dari permasalahan energi kehidupan yang didiskusikan bersama kelompok belajarnya. Berdasarkan teori pendistribusian kognisi yang mengatakan bahwa kegiatan siswa yang memikirkan isu atau soal secara bersama-sama atau berkelompok dengan saling berbagi gagasan dan bekerja secara kolaboratif untuk menarik kesimpulan atau mengembangkan solusi belajar bersama lingkungan dan temannya justru memberikan kemudahan kepada siswa dalam meningkatkan perkembangan intelektualnya untuk menuju Zona of proximal development yaitu zona diantara dua tingkat perkembangan yang berbeda yaitu tingkat perkembangan aktual dan tingkat perkembangan potensial. Hal ini didukung oleh hasil penelitian Miswanto (2011) yang menyatakan bahwa penerapan pembelajaran berbasis proyek pada materi program linear siswa SMK Negeri 1 Singosari menunjukkan interaksi sosial yang terjadi dalam kelompok memberikan pengaruh terhadap peningkatan pemahaman siswa terhadap materi program linear terutama pada penggunaan metode uji titik sudut. 
Peningkatan pemahaman ini diperoleh melalui aktivitas dialog dalam kelompok dan presentasi yang disajikan sehingga membuat siswa yang lain menjadi mudah paham. Hasil penelitian dari Santi (2011) juga menyatakan bahwa pembelajaran melalui Project Based Learning memberikan konstribusi pemahaman pada mata kuliah Fisiologi Tumbuhan dari satu siklus satu ke siklus selanjutnya.

Menurut Vygostky menyatakan bahwa interaksi sosial dengan orang lain dapat memacu pengkonstruksian ide-ide baru dan meningkatkan perkembangan intelektual pelajar. Dalam pembelajaran sosial seorang siswa akan berada pada dua tingkat perkembangan yang berbeda yaitu tingkat perkembangan aktual dan tingkat perkembangan potensial sedangkan zona yang terlatak antara kedua tingkat perkembangan tersebut disebut sebagai Zone of proximal develoment. Pada Tingkat perkembangan aktual menentukan fungsi intelektual individu saat ini dan kemampuannya untuk mempelajari sendiri hal-hal tertentu. Sedangkan tingkat perkembangan potensial yaitu tingkatyang dapat dicapai oleh individu dengan bantuan orang lain yang lebih maju seperti guru, orang tua atau teman sebayanya. Jadi belajar melalui interaksi sosial dengan guru dan teman sebayanya yang lebih mampu, siswa bergerak maju ke dalam zona perkembangan terdekat mereka tempat terjadinya pembelajaran baru (Nur,2011)

Hasil pengamatan terhadap keterampilan berkomunikasi siswa diperoleh dalam dua jenis yaitu (1) keterampilan berkomunikasi dalam melakukan interaksi antar siswa selama penyelesaian tugas secara berkelompok yang berlangsung 8 kali pertemuan dengan 2 indikator penilaian yaitu IK 7 dan IK 8, (2) keterampilan berkomunikasi dalam forum presentasi yang diperoleh dalam 3 kali kegiatan yaitu IK 9. Tingkat keterampilan siswa dalam berkomunikasi dapat dilihat pada gambar 4 berikut ini:

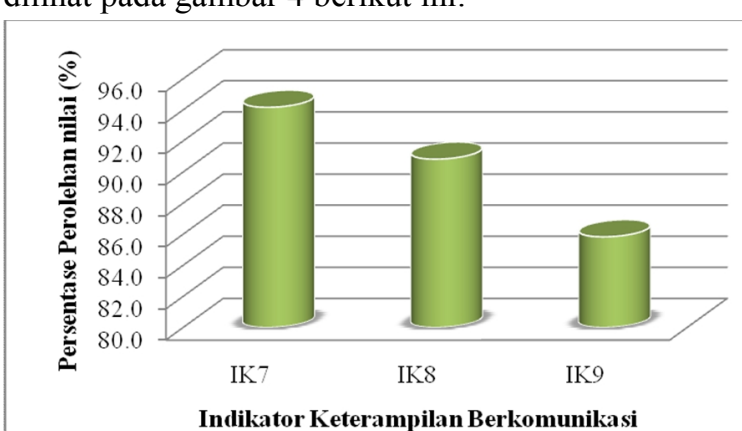

Gambar 4 Tingkat keterampilan berkomunikasi siswa

Gambar 4 diatas menunjukkan tingkat keterampilan mengkomunikasikan materi dengan runtut dan penuh percaya diri (IK9) mencapai 85,8\% siswa sedangkan tingkat keterampilan berkomunikasi dengan menghargai pendapat orang lain (IK7) dan menjadi pendengar yang baik (IK8) masing-masing mencapai $94,2 \%$ dan $90,8 \%$. Hal ini menunjukkan bahwa dengan pembelajaran berbasis proyek mampu melatihkan keterampilan berkomunikasi dan berinteraksi secara personal lebih baik bagi siswa.

Keterampilan sosial membawa siswa untuk lebih berani berbicara, mengungkapkan setiap perasaan atau permasalahan yang dihadapi dan sekaligus menemukan penyelesaian yang adaptif, sehingga melalui interaksi dengan teman sesamanya juga dapat saling memberikan stimulasi untuk saling memotivasi kepada diri dan orang lain. Keberhasilan dalam menghasilkan produk melalui kegiatan proyek memerlukan ide gagasan yang berbeda, kerja tim yang solid dan perencanaan yang baik. Ketiga hal tersebut dapat diwujudkan bila komunikasi antar tim berjalan dengan baik dan adanya pemimpin yang bisa mempengaruhi anggotanya serta setiap anggota melaksanakan tugas sesuai tanggunjawabnya. Selain itu keterampilan dalam melaporkan hasil proyek baik melalui lesan, tulisan bahkan produk gambar merupakan salah satu wujud keberhasilan dalam penyelesaian proyek.

Pada pertemuan terakhir setelah kegiatan presentasi di kelas dilakukan, siswa dalam kelompok juga mempresentasikan ke warga sekolah, teman dalam satu level, teman dalam level atas (kelas yang lebih tinggi), bapak/ibu guru lainnya dan karyawan lain disekolah termasuk kepada petugas keamanan dan kebersihan sekolah. Dari aktivitas tersebut, selain bertujuan untuk mempromosikan kreativitas produknya, memberikan bekal pengalaman presentasi didepan umum, diharapkan juga siswa memiliki percaya diri dan memiliki kebanggan terhadap produk hasil kerja keras mereka. Hal ini juga dibuktikan dengan hasil wawancara terhadap siswa yang sebagian besar menyatakan senang dengan diberikan tantangan tersebut walaupun merasa sedikit tegang. Hal ini selaras dengan data hasil angket yang menunjukkan 53\% siswa menyatakan terbantu dengan mengembangkan keterampilan berkomunikasi di depan umum.

Hubungan antara pembelajaran berbasis proyek terhadap keterampilan sosial juga diperkuat oleh hasil penelitian dari Sudewi dkk (2013) yang menyatakan bahwa selain pembelajaran berbasis proyek dapat meningkatkan keterampilan berpikir kritis siswa kelas X SMK Negeri 1 Sukasada juga dapat meningkatkan keterampilan sosial siswa seperti menggalang kerjasama kelompok, sharing tanggung jawab kepemimpinan, kemampuan mendistribusikan tugas, keberanian dan kemampuan komunikasi secara oral dalam presentasi dan diskusi kelas dengan guru juri, memecahkan konflik kepentingan antar anggota kelompok, keberanian dan kemampuan menghubungi nara sumber, belajar berkomunikasi secara intensif dengan guru pembimbing dengan penuh rasa hormat 
baik pada aktivitas kurikuler maupun kokurikuler, kemampuan mempertahankan pendapat, kemampuan mempengaruhi pikiran dan keyakinan orang lain secara oral, serta mengembangkan kemampuan berdiskusi dengan teman sekelompok atau sekelas.

Pembelajaran berbasis proyek memberikan peningkatan pemahaman siswa terhadap materi energi dalam system kehidupan dengan menunjukkan rata-rata $\mathrm{N}$-gain sebesar 0,8 . Hal ini mengindikasikan bahwa pembelajaran berbasis proyek dengan memberikan aktivitas belajar yang kompleks bagi siswa juga tetap dapat meningkatkan hasil belajar pengetahuan khususnya pada sub materi transforasi energi. Kreativitas produk sains yang telah dihasilkan sangat bervariasi sejumlah 8 produk energi alternatif yaitu bioetanol buah papaya, biogas limbah sayur, briket seresah daun, biodiesel minyak jelantah, briket tempurung kelapa, briket serbuk gergaji, biogas dari enceng gondok dan briket ranting tanaman. Belajar dari konsep materi yang mendasari pembuatan kreativitas produk tersebut siswa dapat lebih mudah mengonstruksi pemahaman dari tingkatan berpikir kongkret menuju tingkat berpikir abstrak. Hal ini sebagaimana yang dikemukakan oleh Jean Piaget dimana siswa kelas VII yang memiliki usia 11-14 tahun berada tingkat perkembangan operasional formal sehingga berada pada masa peralihan dari tahap beripikir kongkret ke abstrak. Sehingga PjBl sangat sesuai dibeajarkan guna melatihkan keterampilan akademik dan juga sosial bagi siswa.

Kerja proyek memuat tugas-tugas yang kompleks berdasarkan pada pertanyaan dan permasalahan (problem) yang sangat menantang dan menuntut siswa untuk merancang, memecahkan masalah, membuat keputuasan, melakukan kegiatan investigasi serta memberikan kesempatan kepada siswa untuk bekerja secara mandiri. Pembelajaran berbasis proyek juga melibatkan aktivitas investigasi konstruktif bagi siswa yang dapat berupa aktivitas mendesain atau merencanakan produk sains, menemukan permasalahan, mengambil keputusan dan memecahkan permasalahan. Selain itu, melibatkan transformasi dan konstruksi pengetahuan yang dapat berupa pengetahuan baru dan atau keterampilan baru selama proses pembelajaran berbasis proyek berlangsung.

Pembelajaran proyek memiliki karakteristik sebagai pembelajaran kolaboratif, keterampilan bekerjasama dan berkomunikasi menjadi salah satu faktor penentu keberhasilan suatu organisasi dalam mencapai target yang diinginkan. Hal ini diperkuat oleh Rais (2010) yang menyatakan bahwa tujuh softskill yang diidentifikasi penting dan harus dikembangkan hingga tingkat pendidikan tinggi meliputi : keterampilan berkomunikasi (communicative skills), keterampilan berpikir dan menyelesaikan masalah (thinking skills and problem solving skills), kekuatan kerja tim (team work force), belajar sepanjang hayat dan pengelolaan informasi (life-long learning and information management), keterampilan wirausaha (entrepreneur skill), etika, moral dan profesionalisme (ethics, moral and professionalism), dan keterampilan kepemimpinan (leadership skills). Sehingga melalui PjBL mampu menyediaan Sumber Daya Manusia (SDM) yang siap terhadap tantangan, persaingan dan handal sehingga mampu bersaing di pasar global nantinya.

\section{KESIMPULAN}

\section{A. Simpulan}

Berdasarkan hasil analisis data dan diskusi hasil penelitian, dapat disimpulkan sebagai berikut :

1. Pembelajaran berbasis proyek $(\mathrm{PjBl})$ dapat melatihkan sejumah keterampilan akademik bagis iswa diantaranya keterampilan dalam mengorgansiisr materi, keterampilan merencanakan, melaksanakan dan melaporkan penugasan proyek serta keterampilan unjuk kerja laboratorium.

2. Pembelajaran berbasis proyek (PjBL) dapat melatihkan pula keterampilan sosial siswa khususnya pada keterampilan bekerjasama dan berkomunikasi sehingga siswa mampu hidup secara berkolaboratif dan penuh kepercayaan diri dalam hidup dengan lingkungan sekitar

3. Pembelajaran berbasis proyek (PjBL) dapat meningkatkan pemahaman siswa terutama dalam mengkontruksi pengetahuan pengintegrasikan beberapa konsep terkait melalui karya nyata kreativitas produk sains.

\section{B. Saran}

Berdasarkan hasil penelitian Pembelajaran IPA Terpadu melalui pembelajaran berbasis proyek yang telah dilakukan, maka peneliti memberikan saran sebagai berikut :

1. Pembelajaran berbasis proyek dapat dijadikan sebagai salah satu alternatif penerapan pembelajaran integratif pada mata pelajaran IPA guna peningkatan pemahaman konsep sekaligus mengembangkan keterampilan akademik dan sosial siswa.

2. Bagi guru yang ingin menerapkan pembelajaran berbasis proyek, hendaknya memilih secara selektif karakteristik materi pembelajaran yang cocok dan memberikan bimbingan secara efektif sehingga kreatifitas siswa tetap ada.

3. Bagi peneliti lain yang berminat mengadakan penelitian serupa hendaknya melakukan pada sekolah lain sehingga dapat diperoleh gambaran lebih lanjut mengenai efektifitas model pembelajaran berbasis proyek pada materi energi dalam kehidupan. 


\section{REFERENSI}

Arends, Richard I. (2008). Learning to Teach, Belajar untuk Mengajar. Edisi ketujuh. Jilid Dua. (diterjemahkan oleh Soedjipto, Helly, P. Dan Soedjipto, Sri, M.) Yogyakarta: Pustaka Pelajar

Bass. Joel E, Contant Terry L, Carin Arthur A (2005). Methods for Teaching Science as Inquiry. $10^{\text {th }}$ edition. Allyn \& Bacon Pearson. United State of America

Cheong, A.C.S., \& Christine, C.M.G. (2002). Teachers' Handbook On Teaching Generic Thinking Skills. New York: Prentice Hall.

Depdikbud, (2013), Peraturan Menteri Pendidikan dan Kebudayaan No. 68 Tahun 2013 tentang Struktur Kurikulum SMP-MTs, Jakarta: Depdikbud

Doppelt, Y. (2003). "Implementation and assessment of project based learning in flexible environment". Instructional Journal of Technology and Design Education.Vol. 13 pp. 255-272

Fogarty, R. (1991). The Mindful School How To Integrate The Curricula. United States of America: IRI/Skylight Publising,Inc.

Okudan, Gul E. dan Sarah E, Rzasa, (2004). ”A ProjectBased Approach to Enterprenurial Leadership Education". Journal Technovation. Desember. Vol. 20. pp. 1-16

Joyce B, Weil M, Calhoun W. (2009). Model of Teaching. Eight Edition.Pearson Education

Kemendikbud. (2013). Materi Pelatihan Implementasi Kurikulum 2013 SMP IPA. Jakarta. Kemendikbud: 228
Miswanto. (2011). "Penerapan Model Pembelajaran Berbasis Proyek Pada Materi Program Linear Siswa Kelas X SMK Negeri 1 Singosari”. Jurnal Penelitian Dan Pemikiran Pendidikan. Vol. 1. No. 1. pp. 60-68

Nur, M. (2011). Model Pembelajaran Berdasarkan Masalah. PSMS. Unesa

Puskur. (2007). Panduan Pengembangan Pembelajaran IPA Terpadu, Sekolah Menengah Pertama/Madrasah Tsanawiyah (SMP/MTs). Jakarta: Balitbang Depdiknas

Rais, M. (2010). "Project Based Learning : Inovasi Pembelajaran Berorientasi Soft Skill”. Makalah Disajikan Pada Seminar Nasional Pendidikan Teknologi dan Kejuruan Fakultas Tehnik Universitas Negeri Surabaya, Surabaya.

Santi, T.K. (2011). "Pembelajaran Berbasis Proyek (Project Based Learning) Untuk Meningkatkan Pemahaman Mata Kuliah Fisiologi Tumbuhan". Jurnal Ilmiah PROGRESSIF. Vol.7 No.21. pp. 74-83

Slavin, Robert E (1995). Coopertaive Learning Teory, Reasearch and Practice. Second Edition. Allyn \& Bacon

Sudewi I.G.A, Suharsono. N, \& Kirna I.M., (2013). "Penerapan Model Pembelajaran Berbasis Proyek Untuk Meningkatkan Kemampuan Berpikir Kritis Pada Siswa Kelas X Mutimedia 3 SMK Negeri 1 Sukasada”. E-Journal Program Pasca Sarjana Universitas Pendidikan Ganesha Program Studi Teknologi Pembelajaran. Vol. 3 